\title{
Lower cost alternatives for molecular diagnosis of COVID-19: conventional RT-PCR and SYBR Green-based RT-qPCR
}

\author{
Erick Gustavo Dorlass ${ }^{1} \cdot$ Cairo Oliveira Monteiro ${ }^{1}$ - Amanda Oliveira Viana ${ }^{1} \cdot$ Camila Pereira Soares $^{1}$. \\ Rafael Rahal Guaragna Machado ${ }^{1}$ • Luciano Matsumiya Thomazelli ${ }^{1}$ • Danielle Bastos Araujo ${ }^{1}$ • Fabyano Bruno Leal ${ }^{1,11}$. \\ Erika Donizette Candido ${ }^{1}$ - Bruna Larotonda Telezynski ${ }^{1}$. Camila Araujo Valério ${ }^{1}$ • Vanessa Nascimento Chalup ${ }^{1}$. \\ Ralyria Mello ${ }^{1}$ - Flavia Jaqueline Almeida ${ }^{2}$ - Andressa Simões Aguiar ${ }^{3,5}$ • Anna Carlotta Mott Barrientos ${ }^{4}$. \\ Carolina Sucupira ${ }^{5}$. Milena De Paulis ${ }^{6}$ - Marco Aurélio Palazzi Sáfadi ${ }^{2}$. Daniella Gregorio Bonfim Prado Silva ${ }^{3}$. \\ Janaina Joice Martins Sodré ${ }^{4}$. Mariana Pereira Soledade ${ }^{5} \cdot$ Samantha Faria Matos $^{2} \cdot$ Sabrina Rodrigues Ferreira $^{4}$.

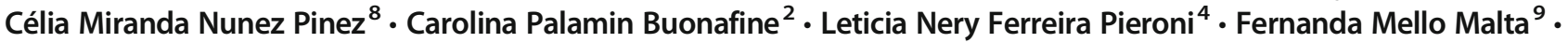 \\ Rubia Anita Ferraz Santana ${ }^{9}$. Eloisa Corrêa Souza ${ }^{6}$ - Ricardo Ambrosio Fock ${ }^{7,8}$ • João Renato Rebelo Pinho ${ }^{9,10}$. \\ Luís Carlos Souza Ferreira $^{1}$ • Viviane Fongaro Botosso ${ }^{11}$ • Edison Luiz Durigon ${ }^{1,12}$ • Danielle Bruna Leal Oliveira ${ }^{1,11,13}$ (D)
}

Received: 18 May 2020 / Accepted: 22 July 2020 / Published online: 7 August 2020

(C) Sociedade Brasileira de Microbiologia 2020

\begin{abstract}
In March 2020, WHO declared a pandemic state due to SARS-CoV-2 having spread. TaqMan-based real-time RT-qPCR is currently the gold standard for COVID-19 diagnosis. However, it is a high-cost assay, inaccessible for the majority of laboratories around the world, making it difficult to diagnose on a large scale. The objective of this study was to standardize lower cost molecular methods for SARS-CoV-2 identification. E gene primers previously determined for TaqMan assays by Colman et al. (2020) were adapted in SYBR Green assay and RT-PCR conventional. The cross-reactivity test was performed with 17 positive samples for other respiratory viruses, and the sensibility test was performed with 8 dilutions (10 based) of SARS-CoV-2 isolated and 63 SARS-CoV-2-positive samples. The SYBR Green assays and conventional RT-PCR have not shown amplification of the 17 respiratory samples positives for other viruses. The SYBR Green-based assay was able to detect all 8 dilutions of the isolate.
\end{abstract}

Erick Gustavo Dorlass, Cairo Oliveira Monteiro, Amanda Oliveira Viana and Camila Pereira Soares contributed equally to this work.

Responsible Editor: Marina Baquerizo Martinez.

Electronic supplementary material The online version of this article (https://doi.org/10.1007/s42770-020-00347-5) contains supplementary material, which is available to authorized users.

Danielle Bruna Leal Oliveira

danibruna@gmail.com

1 Department of Microbiology, Institute of Biomedical Sciences, University of São Paulo, São Paulo, Brazil

2 Department of Pediatrics, School of Medical Sciences, Santa Casa de Misericórdia de São Paulo, São Paulo, Brazil

3 Infection Control Service, São Luiz Gonzaga Hospital of Santa Casa de Misericordia of São Paulo, São Paulo, Brazil

4 Infection Control Service, Municipal Children's Hospital Menino Jesus, São Paulo, Brazil

5 Infection Control Service and Epidemiological Hospital Nucleo, Municipal Children's Hospital Candido Fontoura, São Paulo, Brazil

6 Department of Pediatrics, University Hospital, School of Medicine, University of São Paulo, São Paulo, Brazil
7 Department of Clinical and Toxicological Analysis, School of Pharmaceutical Sciences, University of São Paulo, São Paulo, Brazil

8 Clinical Laboratory Division, Pharmacy and Clinical Laboratory Department, University Hospital, University of São Paulo, São Paulo, Brazil

9 Clinical Laboratory, Hospital Israelita Albert Einstein, São Paulo, Brazil

10 LIM03/07 Clinics Hospital, School of Medicine, University of São Paulo, São Paulo, Brazil

11 Development and Innovation Center, Laboratory of Virology, Butantan Institute, São Paulo, Brazil

12 Scientific Platform Pasteur USP, São Paulo, Brazil

13 Clinical and Molecular Virology Laboratory, University of São Paulo, Av. Prof. Lineu Prestes 1374, São Paulo, SP 05508-900, Brazil 
The conventional PCR detected until $10^{7}$ dilution, both assays detected the majority of the 63 samples, $98.42 \%$ of positivity in SYBR Green, and 93\% in conventional PCR. The average $C t$ variation between SYBR Green and TaqMan was 1.92 and the highest $C t$ detected by conventional PCR was 35.98. Both of the proposed assays are less sensitive than the current gold standard; however, our data shows a low sensibility variation, suggesting that these methods could be used by laboratories as a lower cost molecular method for SARS-CoV-2 diagnosis.

Keywords COVID-19 pandemic $\cdot$ Molecular diagnoses $\cdot$ Conventional PCR $\cdot$ SYBR Green assay $\cdot$ SARS-CoV-2

\section{Introduction}

In December 2019, an increase in the number of severe pneumonia cases was reported in China, more specifically in the Hubei Province [1]. In January, the causative agent was identified as a new $\beta$-coronavirus, the SARS-CoV-2. The progressive number of cases and the fast dissemination to other countries led the World Health Organization (WHO) to officially declare the COVID-19 epidemic as a public health emergency of international concern. In March, WHO declared COVID19 a pandemic infection. According to WHO (last update: 2 May 2020), 215 countries or territories were affected with 238.628 deaths and more than 3.349 .786 confirmed cases [2].

In Brazil, the first case of COVID-19 was confirmed on February 26 in the State of São Paulo, considered the epicenter of the disease in the country [3]. Since then, the number of confirmed cases has been growing, steadily reaching the highest number of cases by day at the beginning of April, with around 1000 cases per day (Brazil, Ministry of Health, 2020 - https:// covid.saude.gov.br). Until May 2, 2020, the total number of cases was 96.559 with 6.750 deaths (lethality rate of $\sim 6.8 \%$ ). However, only severe cases were tested due to a lack of testing reagents in the market and the number of cases can be far higher.

For this reason, the WHO advises that, in addition to isolation, massive diagnostic testing must be implemented in affected areas [4]. The SARS-CoV-2 testing capacity is a major issue worldwide and the development of alternative tests is urgently needed, particularly in developing countries where availability of supplies or infrastructure to carry out the real-time PCR test is limited. Thereby, the aim of this study was the standardization of alternative molecular methods, with lower cost and easier availability of reagents, for the diagnosis of COVID-19. It was based on the SYBR Green method and conventional PCR utilizing primers described by Corman et al. [5].

\section{Materials and methods}

\section{Sample collection}

A total of 700 nasopharyngeal (NP)/oropharyngeal (OP) swabs was collected from symptomatic patients and asymptomatic/healthcare worker during SARS-CoV-2 outbreak in the city of São Paulo, Brazil (from February 28 to April 28), and 184 (26.3\%) were positive by qRT-PCR, from which 63 positive samples were selected for the study. The selection of the 63 nasopharyngeal (NP)/oropharyngeal (OP) samples from 700 patients with suspected COVID-19 was carried out according to the $C t$ (cycle threshold) that were split into three different groups according to the $C t$ : Group 1 was composed of 19 samples with $C t$ ranging from 15.00 to 20.99. Group 2 was composed of 27 samples with $C t$ ranging from 21.00 to 29.99 and group 3 was composed of 17 samples with $C t$ ranging from 30.00 to 38.99 . All considered positive by real-time PCR According to Corman et al. [5]. The samples were collected in five hospitals in the São Paulo City: (1) University Hospital at São Paulo University (HU-USP); (2) Santa Casa da Misericórdia Hospital (SCMH); (3) Hospital São Luiz Gonzaga (HSLG); (4) Infant Hospital Candido Fontoura (IHCF); (5) Pediatric Hospital Menino Jesus (PHMJ). The samples were divided into three different age groups, with 8 samples under the age of 18 years (school age), 52 samples were from patients aged 19 to 60 years (adult age), and 3 samples were from patients over 60 years of age (adult in the risk group). The study protocol was approved by the Ethics Committee on Research with Human Beings at the University of São Paulo and all the procedures followed the ethical guidelines for human experimentation (CAAE) 74683917.1.0000.5467.

\section{RNA extraction and CDNA obtention}

The extraction of RNA from clinical samples was carried out on the NucliSens easyMag ${ }^{\circledR}$ platform fully automated (BioMerieux, Lyon, France) and all 63 samples selected in this study also were extracted using guanidinium isothiocyanate phenol (Brazol, LGC Biotecnologia, Brazil), according to the manufacturer's instructions. We used as positive controls a clinical isolated in Vero-E6 cell culture (SARS.COV-2/SP02/ human2020/Br, GenBank accession number MT126808.1) and water with a negative control. For complementary DNA (cDNA) synthesis, when necessary, we used the HighCapacity cDNA Reverse Transcription kit (Applied Biosystems, Weiterstadt, Germany) following the manufacturer's instructions. Briefly, $10 \mu \mathrm{L}$ of the extracted sample is diluted in a mix of $3.2 \mu \mathrm{L}$ of DEPC-treated water, $2 \mu \mathrm{L}$ of RT 
Buffer ( $\times 10$ concentrate), $2 \mu \mathrm{L}$ of RT Random Primers $(\times 10$ concentrate), $0.8 \mu \mathrm{L}$ of dNTP mix $(100 \mathrm{mM}), 1 \mu \mathrm{L}$ of RNase inhibitor $(20 \mathrm{U} / \mu \mathrm{L})$, and $1 \mu \mathrm{L}$ of Multiscribe ${ }^{\mathrm{TM}}$ Reverse Transcriptase $(50 \mathrm{U} / \mu \mathrm{L})$. The reverse transcriptase reaction carried in Veriti Thermal Cycler (Applied Biosystems) following the cycling: $25^{\circ} \mathrm{C}$ for $10 \mathrm{~min}, 37^{\circ} \mathrm{C}$ for $120 \mathrm{~min}$, and $85^{\circ} \mathrm{C}$ for $5 \mathrm{~min}$.

\section{Cross reactivity among SARS-Cov-2 and other respi- ratory viruses}

All the steps of molecular biology diagnosis followed strict procedures to prevent contamination, including redundant negative controls and segregated environments for pre- and post-amplification procedures. For evaluation of cross reactions with other viruses, the genetic material of 15 respiratory viruses: influenza A virus ( $\operatorname{Inf} A$ ), influenza B virus ( $\operatorname{Inf} B$ ), seasonal coronaviruses (CoV-NL63, -229E, -HKU1, and OC43), enterovirus (EV), parainfluenza viruses (PIV-1, -2, 3 and -4 ), human metapneumovirus (HMPV), rhinovirus (RV), respiratory syncytial virus (RSV), and adenovirus $(\mathrm{AdV})$. The samples were tested using a panel of validated in-house singleplex real-time RT-qPCR assays developed at the Centers for Disease Control and Prevention (CDC, Atlanta, GA, USA), for 15 respiratory viruses, according to Sakthivel et al. [6] and for SARS-CoV-2 according to Corman et al. [5] by real-time RT-qPCR by TaqMan protocol.

\section{SYBR Green-based in real time for SARS-Cov-2 diagnosis}

The SYBR Green RT-qPCR assay (one step) was performed, according to the manufacturer's recommendations, with the QuantiFast SYBR® Green RT-PCR kit (QIAGEN, Hilden, Germany). Briefly, $8 \mu \mathrm{L}$ of target RNA and $1 \mu \mathrm{L}$ $[10 \mathrm{pM} / \mu \mathrm{L}]$ from each primer (E-Sarbeco F1 and R2) [5] were added to the $12.5 \mu \mathrm{L} 2 \mathrm{x}$ Master Mix QuantiFast SYBR Green RT-PCR, $0.25 \mu \mathrm{L}$ of enzyme RT-Mix and Ultra-Pure Water (Thermo Fisher Scientific, Waltham, MA, USA) to complete $25 \mu \mathrm{L}$ of reaction. The reverse transcription reaction was performed at $50{ }^{\circ} \mathrm{C}$ for $10 \mathrm{~min}$, followed by 5 -min denaturation at $95^{\circ} \mathrm{C}, 40$ cycles of $95^{\circ} \mathrm{C}$ for $10 \mathrm{~s}$, and $60^{\circ} \mathrm{C}$ for $30 \mathrm{~s}$. The reaction was completed by determining the dissociation curve of all amplicons generated in the ABI 7500 device (Applied Biosystems, Weiterstadt, Germany). The SYBR Green qPCR reactions (two steps) were carried out in a $20-\mu \mathrm{L}$ final volume containing $10 \mu \mathrm{L}$ of 2 X PowerUp SYBR Green PCR Master Mix (Applied Biosystems, Weiterstadt, Germany), $2 \mu \mathrm{L}$ of each primer $[10 \mathrm{pM} / \mu \mathrm{L}], 5 \mu \mathrm{L}$ of $\mathrm{cDNA}$, and $1 \mu \mathrm{L}$ of UltraPure Water (Thermo Fisher Scientific, Waltham, MA, USA). The thermal cycling conditions used were as follows: $50{ }^{\circ} \mathrm{C}$ for $2 \mathrm{~min}$, followed by $5 \mathrm{~min}$ denaturation at $95{ }^{\circ} \mathrm{C}$, followed by 40 cycles at $95{ }^{\circ} \mathrm{C}$ for $15 \mathrm{~s}, 58^{\circ}$ for $15 \mathrm{~s}$, and $72^{\circ} \mathrm{C}$ for
$1 \mathrm{~min}$, and a dissociation curve was subsequently made. Both reactions were performed using an ABI 7500 machine (Applied Biosystems).

\section{Conventional RT-PCR for SARS-CoV-2 diagnosis}

Two conventional RT-PCR methods were tested, including one-step RT-PCR and two-steps PCR. The one-step protocol used the Pyromark OneStep RT-PCR kit (QIAGEN, Hilden, Germany) according to the manufacturer's instruction. Briefly, $5 \mu \mathrm{L}$ of extracted material was diluted in a $20-\mu \mathrm{L}$ mix containing $5 \mu \mathrm{L}$ of OneStep Buffer $(\times 5$ concentrate, $12.5 \mathrm{mM}$ of $\mathrm{MgCl} 2$, Tris $\mathrm{Cl}, \mathrm{KCl},(\mathrm{NH} 4) 2 \mathrm{SO} 4), 5 \mu \mathrm{L}$ of QSolution $(\times 5$ concentrate $), 1 \mu \mathrm{L}$ of $\mathrm{dNTP}(2.5 \mathrm{mM}$ of each base), $10 \mu \mathrm{M}$ of each primer (E-Sarbeco F1 and R2) [5], $1 \mu \mathrm{L}$ of Qiagen OneStep RT-PCR Enzyme Mix, and $6 \mu \mathrm{L}$ Nuclease Free Water totalizing $25 \mu \mathrm{L}$ final volume. As an alternative method, we also used the Kit PROBE One -Step RT-qPCR (LGC Biotecnologia, Brazil), according to the manufacturer's instruction. The reactions were carried in Veriti Thermal Cycler (Applied Biosystems) following the cycling: $50{ }^{\circ} \mathrm{C}$ for $30 \mathrm{~min}, 95{ }^{\circ} \mathrm{C}$ for $15 \mathrm{~min}$ followed by 45 cycles of $94{ }^{\circ} \mathrm{C}$ for $30 \mathrm{~s}, 58{ }^{\circ} \mathrm{C}$ for $30 \mathrm{~s}, 72{ }^{\circ} \mathrm{C}$ for $30 \mathrm{~s}$, and a final extension of $72{ }^{\circ} \mathrm{C}$ for $10 \mathrm{~min}$. The two-steps PCR reaction were performed with Invitrogen Taq Platinum Polymerase kit, where $5 \mu \mathrm{L}$ of cDNA previously obtained was added to a $20-\mu \mathrm{L}$ mix of $14.2 \mu \mathrm{L}$ DEPC-treated water, $2.5 \mu \mathrm{L}$ of PCR Buffer ( $\times 10$ concentrate), $0.5 \mu \mathrm{L}$ of $\mathrm{MgCl} 2$ [50 mM], $0.5 \mu \mathrm{L}$ of dNTP (2.5 mM of each base), $10 \mu \mathrm{M}$ of each primer ${ }^{8}$, and 1.5 U of Taq Platinum Polymerase for a final volume of $25 \mu \mathrm{L}$. The reaction occurred in Applied Biosystems 9700 Thermal Cycler in the following cycling: $95{ }^{\circ} \mathrm{C}$ for $2 \mathrm{~min}$ followed by 35 cycles of $94{ }^{\circ} \mathrm{C}$ for $15 \mathrm{~s}, 58{ }^{\circ} \mathrm{C}$ for $15 \mathrm{~s}$, $72{ }^{\circ} \mathrm{C}$ for $15 \mathrm{~s}$, and a final extension of $72{ }^{\circ} \mathrm{C}$ for $7 \mathrm{~min}$. Amplified products from both methodologies were submitted to electrophoresis in agarose gel diluted in TAE buffer (LGC Biotechnologies $)(\times 0.5$ concentrate $)$ and stained with ethidium bromide (Invitrogen) for observation of the expected amplified fragment (113 base pairs).

\section{Analytical sensitivity}

The analytical sensitivity of the assays was determined with 8 serials 10-fold dilutions with an isolated sample of the SARSCoV-2. The SARS-CoV-2/SP02/human/2020/BRA (GenBank accession number MT126808.1) strain is a clinical isolated, propagated and titrated in Vero-E6 cells, from Instituto Adolfo Lutz (ATCC), and stored in liquid nitrogen in our laboratories as ICB-Cell-Culture-Collection. All 8 diluted samples were tested by gold standard TaqMan RTqPCR and the resulting cycle threshold $(\mathrm{Ct})$ values were compared for the determination of viral titers. We also tested each of the proposed assays with 63 SARS-CoV-2-positive 
samples previously tested by TaqMan-based real-time RTqPCR in our laboratory. The obtained $\mathrm{Ct}$ was subsequently compared with the results generated with SYBR Green-based real-time qPCR. The limit of detection of SYBR Green RTPCR and conventional RT-PCR was determined using synthetic RNA-positive controls provided by the University of Charité (Germany) and serial dilutions of the virus isolate.

\section{Results}

For the present study, we evaluated the performance of two molecular methods. As the first step, we determined the specificity of the tests and, as shown in Table 1 , none of the 17 clinical samples positive for other respiratory viruses was amplified by the proposed methods (Fig. S1). In addition, 36 previously negative samples for SARS-CoV-2 by the TaqMan RT-qPCR method were also negative in all the other two methods, showing $100 \%$ specificity (Table 1 ).

To evaluate the sensitivity of the two alternative molecular diagnostic tests, we first tested the SYBR Green RT-qPCR. The method showed positive reactions with all serial dilutions of the SARS-Cov-2 isolate with $\mathrm{Ct}$ values ranging from 2.79 to 3.77 (3.51 average) with regard to the gold standard RTqPCR by the TaqMan protocol (Fig. 1a and b; Table S1). On the other hand, The RT-PCR methods (one-step RT-PCR and two-steps PCR amplified the DNA fragment with the expected size until dilution $10^{-7}$ (Fig. 1c and d, respectively). No other fragments with sizes different of $113 \mathrm{bp}$ were observed.

Of the 63 clinical samples identified by RT-qPCR by the TaqMan method [5], only one was negative by the SYBR Green RT-qPCR method (36.95 TaqMan $C t$ value). The $C t$ values of both methods were similar to a difference in $C t$ of 1.92 on average (Fig. 2a). In addition, 59 out of 63 samples (93\%) were clearly detected by the tested one-step and two-step RT-PCR methods (Fig. 2b and $\mathrm{c}$ ). The unamplified samples by these methods have $C t$ values ranging from 36.16 to 38.99 by the TaqMan RT-qPCR. Thus, the tested RT-PCRs could detect positive samples with maximal $C t$ of 35.98. All results generated by the tested alternative methods are shown in the Supplementary Material (Table S2).

\section{Discussion}

The rapid spread and elevated morbidity and mortality rates of the SARS-CoV-2 led to a global public health emergency state. Statistical analyses suggest that several millions will be infected in the coming months [7, 8], challenging public health systems and highlighting the importance of efficient diagnostic tests for preventing virus dissemination. The current gold standard diagnostic method for COVID-19, based on the TaqMan RT-qPCR assay, is efficient but not accessible to laboratories in developing countries based on the elevated costs and the present global demands for supplies and reagents. Thus, the use of reference primer sets for conventional amplification protocols could represent low-cost alternatives with preserved specificity and sensibility [9]. Our results demonstrated that both SYBR Green RT-qPCR assay and two conventional RT-PCR protocols represent valuable alternatives for the molecular detection of SARS-CoV-2.

None of the tested alternative diagnostic methods showed amplification of another respiratory virus, including other $\beta$ -
Table 1 Sensitivity and specificity of SYBR Green RTqPCR and conventional RT-PCR (one and two steps) using TaqMan RT-qPCR $(\mathrm{Ct}<40)$ as a gold standard of 116 clinical samples

\begin{tabular}{llc}
\hline & TaqMan & \\
\hline SYBR Green & Positive $(\mathrm{Ct}<40)$ & Negative $(\mathrm{Ct}>40)$ \\
Positive (MC =75.78) & 62 & 0 \\
Negative (MC40) & 01 & $53 *$ \\
Sensitivity of SYBR Green [95\% IC] & $98.4 \%[97.6-99.8 \%]$ & \\
Specificity of SYBR Green [95\% IC] & $100 \%[98.8-100 \%]$ & \\
Positive predictive value [95\% IC] & $100 \%[94.2-100 \%]$ & \\
Negative predictive value [95\% IC] & $98.1 \%[90.1-99.5 \%]$ & $53 *$ \\
Conventional PCR & & \\
Positive ( 113 bp) & 58 & \\
Negative (113 bp) & 05 & \\
Sensibility of PCR [95\% IC] & $92.1 \%[89.6-95.3 \%]$ & \\
Specificity of PCR [95\% IC] & $100 \%[98.8-100 \%]$ & \\
Positive predictive value [95\% IC] & $100 \%[93.8-100 \%]$ & \\
Negative predictive value [95\% IC] & $91.3 \%[81.0-97.1 \%]$ & \\
\hline
\end{tabular}

*From which 17 samples are positives for other respiratory viruses 

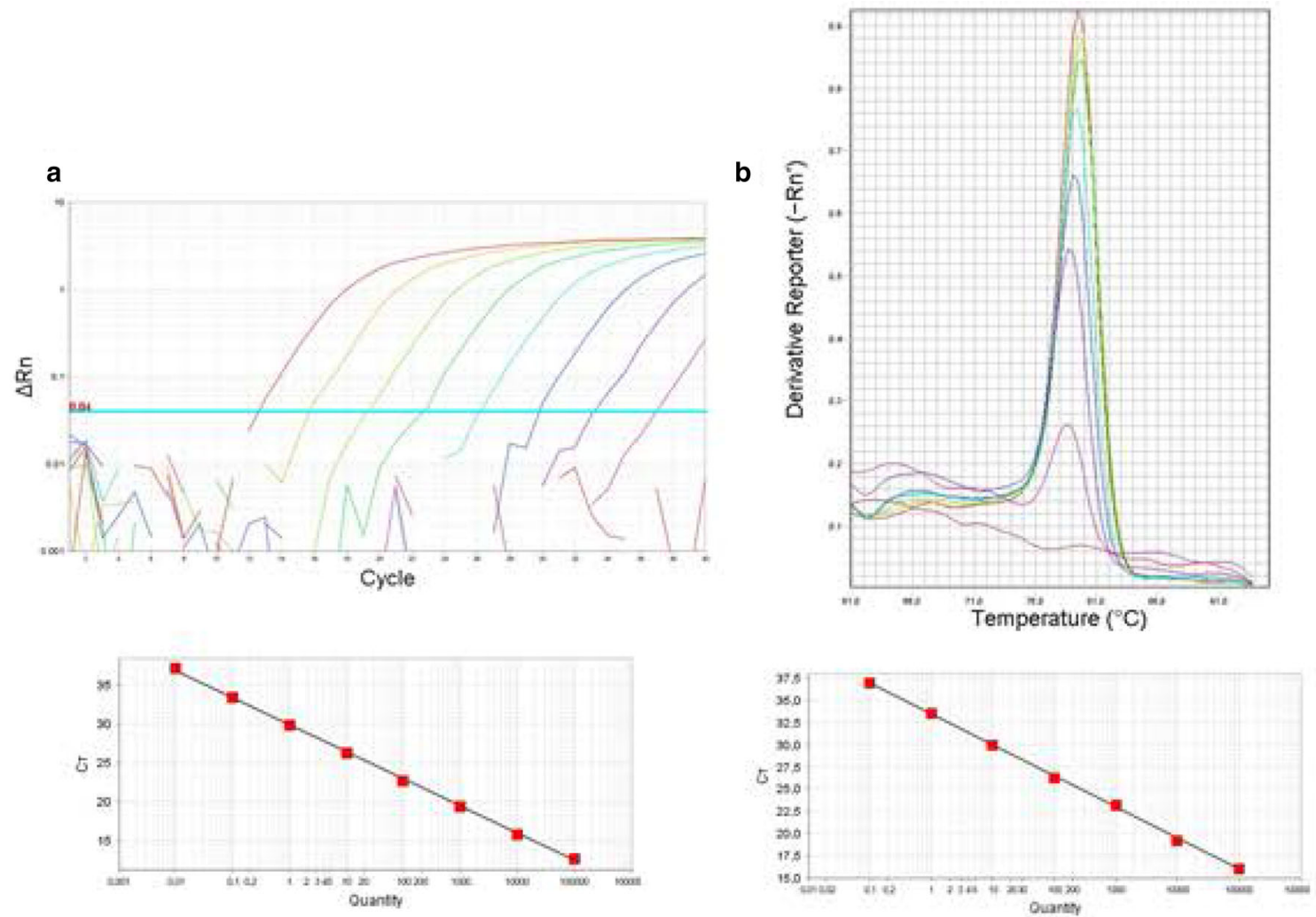

C
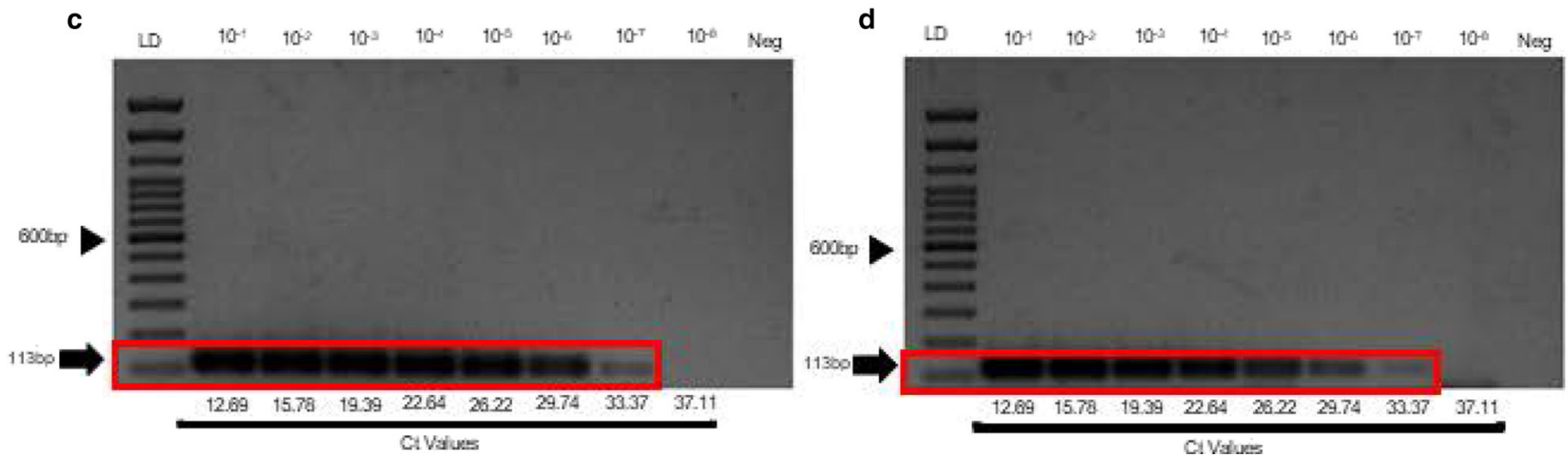

Fig. 1 Analytical sensitivity of the tested molecular diagnostic methods using the Brazilian SARS-CoV-2 isolate. a Standard curve for absolute quantification by TaqMan real-time PCR. Amplification plot and linear regression of standard curve, slope - 3.494, R2 0.99, Eff\% 93.284. b Melting curve and linear regression of the standard curve, slope 3.497, R2 0.99, Eff\% 9.168. c and d Agarose gels of one-step RT-PCR

and two-steps RT-PCR, respectively. The 600-bp marker in the ladder (LD) is displayed in the gel. The arrow marks the amplified fragment of 113 base pairs (bp) amplified with the SARS-CoV-2-specific E gene primers. Each dilution is displayed in the top of gels as well as the cycle threshold $(\mathrm{Ct})$ values, at the bottom of the pictures. The observed amplifications are indicated by the red boxes

coronavirus (HKU and OC43), besides the SARS-CoV-2. These results support a previous report of Corman et al. [5]. In addition, our data indicate that the probes recommended for the detection of the SARS-CoV-2 by the TaqMan RT-qPCR are not the only ones capable to confer the required specificity with regard to other respiratory viruses.

The SARS-CoV-2 was capable to detect all tested dilutions of the Brazilian SARS-CoV-2 isolate with low $\mathrm{Ct}$ value differences with regard to the reference method. On the other hand, the two tested conventional RT-PCR assays were capable to detect the genetic material of the virus up to a $10^{-7}$ dilution (corresponding to a $\mathrm{Ct}$ value of 33.37 in the reference TaqMan RT-qPCR) in agarose gels. The higher sensitivities of both RT-qPCR methods in comparison to RT-PCR methods were expected [9-11]. Nonetheless, we believe that conventional RT- 
Fig. 2 Comparison of $\mathrm{Ct}$ values obtained by TaqMan, SYBR Green, and one-step/two-step RTPCR assays. a $\mathrm{Ct}$ values of 63 clinical samples detected with TaqMan and SYBR Green RTqPCR. b, c Agarose gels of amplified fragments by one-step RTPCR and two-step PCR assays, respectively, of 14 representatives' clinical samples. The 600bp marker in the ladder (LD) is indicated in the picture. The arrow points to the fragment of 113 base pairs (bp) amplified with SARS$\mathrm{CoV}$-2-specific E gene primers

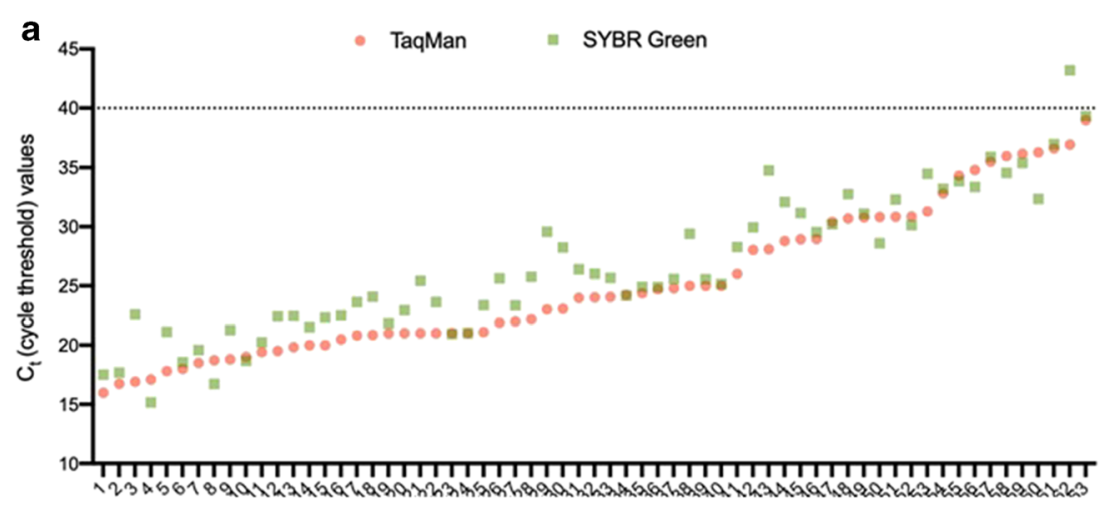

b LD

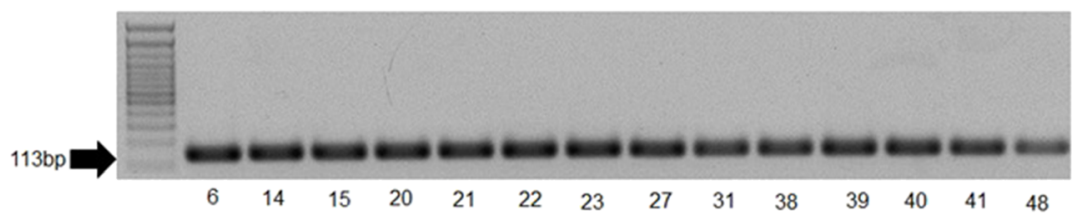

C

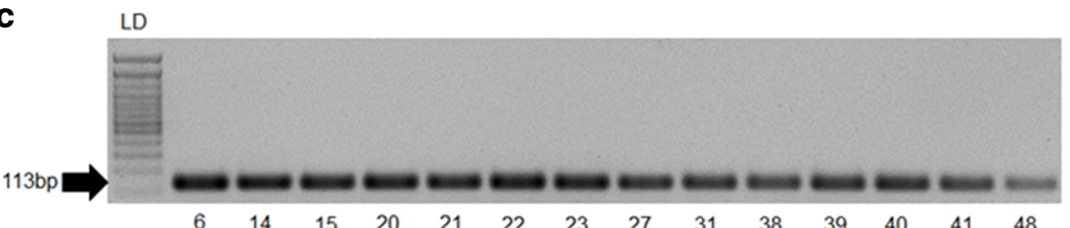

PCR methods may be adequate to detect the virus at the onset of the disease symptoms and among patients with severe symptoms when higher viral loads are observed $[12,13]$. Furthermore, adding higher RNA or cDNA loads in the reaction mix may improve the sensitivity of the tests and, consequently, enhance the detection of lower viral loads.

Although the conventional RT-PCR method requires more time to deliver the result, the technique still proved to be very efficient and indispensable in times of pandemic, where even in the most remote places in the world the diagnosis can be made.

In summary, the two protocols tested were suitable for the detection of SARS-CoV-2 in clinical samples, particularly in places where the reference TaqMan RT-qPCR is not available. Thus, the proposed protocols represent alternatives with lowcost reagents and readily available for the screening and molecular diagnosis of COVID-19; however, it would be necessary and extremely important that the health departments and health ministries of each country or city, validate and officially release the use of these methods as recognized diagnostics for COVID-19.

Acknowledgments We thank José Lopes from LVCM-USP and Gabriela Carolina Fernandes Leite from Malaria Laboratory for technical support at the diagnosis.
Author contributions Writing, review editing, and original draft preparation: D.B.L.O., E.G.D., C.O.M., A.O.V., C.P.S., R.R.G.M., L.M.T., R.A.F., L.C.S.F., V.F.B., E.L.D.; laboratory diagnosis analysis: E.G.D., C.O.M., A.O.V., C.P.S., R.R.G.M., F.B.L., E.D.C., B.L.T., C.A.V., V.N.C., R.M., C.M.N.P.; hospital clinical evaluation, sample collection, and patients clinical: F.J.A., A.S.A., A.C.M.B., C.S., M.D.P., M.A.P.S., D.G.B.P.S., J.J.M.S., S.F.M., S.R.F., C.P.B., L.N.F.P., F.M.N., R.A.F.S., L.C.S.; supervision and funding acquisition: E.L.D., L.C.S.F., V.F.B., D.B.L.O.

Funding information Funding was granted by Fundação de Amparo à Pesquisa do Estado de São Paulo (FAPESP), projects n ${ }^{\circ}$ 2016/20045-7 (LCSF and ELD) and Conselho Nacional de Pesquisa (CNPq) Project 440409/2016-0 (LCSF). FAPESP fellowship: 2018/23680-0 (COM), 2018/23680-0 (CPS), 2017/24769-2 (RRGM), 2017/25123-9 (AOV); CAPES fellowship: 1742355 (EGD), 8887.131387/2016-00 (DBA).

Availability of data and material Available in request.

\section{Compliance with ethical standards}

Conflict of interest The authors declare that they have no conflict of interest.

Ethics approval Our institutional review board approved this study and all biological samples were collected under the approval of the Ethics Committee of the Institute of Biomedical Science (ICB), USP.

Code availability Not applicable. 


\section{References}

1. Zhu N, Zhang D, Wang W, Li X, Yang B, Song J, Zhao X, Huang B, Shi W, Lu R, Niu P, Zhan F, Ma X, Wang D, Xu W, Wu G, Gao GF, Tan W, China Novel Coronavirus Investigating and Research Team (2020) A novel coronavirus from patients with pneumonia in China, 2019. N Engl J Med 382:727-733. https://doi.org/10.1056/ NEJMoa2001017

2. Organization WH (2020) Situation Report-83 HIGHLIGHTS

3. Rodriguez-Morales AJ, Gallego V, Escalera-Antezana JP, Méndez CA, Zambrano LI, Franco-Paredes C, Suárez JA, Rodriguez-Enciso HD, Balbin-Ramon GJ, Savio-Larriera E, Risquez A, Cimerman S (2020) COVID-19 in Latin America: the implications of the first confirmed case in Brazil. Travel Med Infect Dis. Elsevier USA 35: 101613. https://doi.org/10.1016/j.tmaid.2020.101613

4. World Health Organization (2020) Laboratory testing strategy recommendations for COVID-19

5. Corman VM, Landt O, Kaiser M, Molenkamp R, Meijer A, Chu DK et al (2020) Detection of 2019 novel coronavirus (2019-nCoV) by real-time RT-PCR. Eurosurveillance 25:2000045. https://doi. org/10.2807/1560-7917.ES.2020.25.3.2000045

6. Sakthivel SK, Whitaker B, Lu X, Oliveira DBL, Stockman LJ, Kamili S, Oberste MS, Erdman DD (2012) Comparison of fasttrack diagnostics respiratory pathogens multiplex real-time RTPCR assay with in-house singleplex assays for comprehensive detection of human respiratory viruses. J Virol Methods 185:259266. https://doi.org/10.1016/j.jviromet.2012.07.010

7. Nesteruk I (2020) Long-term predictions for COVID-19 pandemic dynamics in Ukraine, Austria and Italy. medRxiv; 2020.04.08.20058123. https://doi.org/10.1101/2020.04.08. 20058123
8. Ciufolini I, Paolozzi A (2020) Prediction of the time evolution of the Covid-19 pandemic in Italy by a Gauss error function and Monte Carlo simulations. medRxiv; 2020.03.27.20045104. https://doi.org/10.1101/2020.03.27.20045104

9. Tajadini M, Panjehpour M, Javanmard S (2014) Comparison of SYBR Green and TaqMan methods in quantitative real-time polymerase chain reaction analysis of four adenosine receptor subtypes. Adv Biomed Res 3:85. https://doi.org/10.4103/2277-9175.127998

10. Kim DW (2001) Real time quantitative PCR. Exp Mol Med 33: 101-109. https://doi.org/10.1101/gr.6.10.986

11. Paudel D, Jarman R, Limkittikul K, Klungthong C, Chamnanchanunt S, Nisalak A, Gibbons R, Chokejindachai W (2011) Comparison of real-time SYBR green dengue assay with real-time taqman RT-PCR dengue assay and the conventional nested PCR for diagnosis of primary and secondary dengue infection. N Am J Med Sci 3:478-485. https://doi.org/10.4297/najms. 2011.3478

12. Zou L, Ruan F, Huang M, Liang L, Huang H, Hong Z, Yu J, Kang M, Song Y, Xia J, Guo Q, Song T, He J, Yen HL, Peiris M, Wu J (2020) SARS-CoV-2 viral load in upper respiratory specimens of infected patients. N Engl J Med. Massachussetts Medical Society: 1177-1179. https://doi.org/10.1056/NEJMc2001737

13. Liu Y, Yan LM, Wan L, Xiang TX, Le A, Liu JM et al (2020) Viral dynamics in mild and severe cases of COVID-19. Lancet Infect Dis. Lancet Publishing Group. https://doi.org/10.1016/S1473-3099(20) 30232-2

Publisher's note Springer Nature remains neutral with regard to jurisdictional claims in published maps and institutional affiliations. 